\title{
Following Congdon - 53 Years Later
}

By STUART and MARY HOUSTON

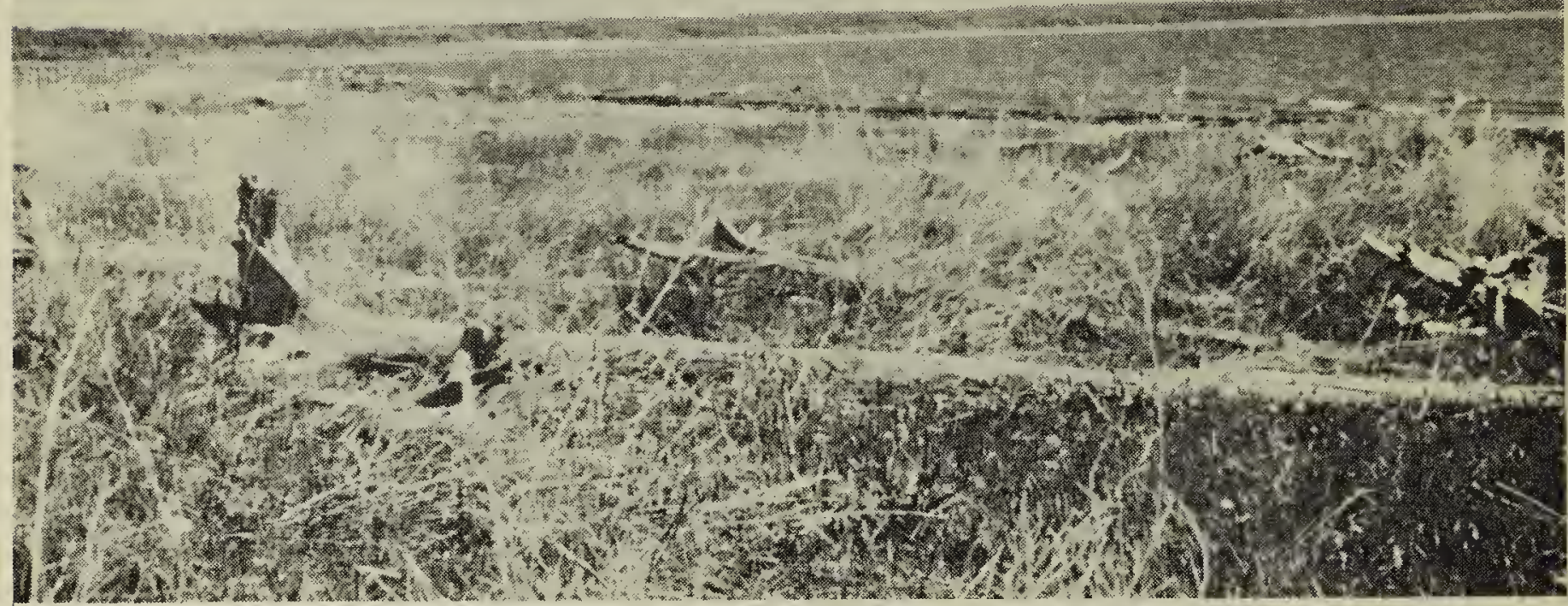

Basin Lake. Photo by Stuart Houston

The Transactions of the Wisconsin Academy of Sciences, Arts and Letters, for 1903, contained on pages 569-620 a paper by Russell T. Congdon, entitled "Saskatchewan Birds". This dealt with Congdon's observations during the summer of 1902, when he set out from Prince Albert and visited "Crooked" (Wakaw), Basin, Middle and Lenore Lakes, and then spent most of the summer at the Waterhen Marsh near Kinistino.

Congdon listed a total of 85 species, with considerable detail as to where they occurred, their habits, and nesting records. 14 excellent photographs illustrated the paper.

Two of these species were seen at Saskatoon en route (Snowy Owl and Ferruginous Rough-leg), three species were seen only at Prince Albert (Spruce Grouse, Pileated Woodpecker and Canada Jay), and two species must be considered hypothetical (Swamp Sparrow and Chestnut-collared Longspur). This left 78 species definitely identified in the Wakaw-Basin-Middle-Lenore Lakes - Waterhen Marsh area.

Since 1955 was Jubilee Year, we felt it would be fun to spend three days of our holiday in this region, and see what changes had taken place in the bird life since 1902. One must realize what great changes had taken place in 53 years: Congdon in
1902 travelled slowly and laboriously with a team and wagon over littleused trails. His only aid was a folding canvas boat. We in 1955 had a modern car, graded roads, and the inestimable advantage of good binoculars and modern field guides to make identification easy.

We spent June 13 th, June 14 th and part of June 15th in the district explored by Congdon. Our best day of birding was June 14 th, when we saw 75 species, and heard an additional 5 species. Our total for the three days was 93 species seen, and an additional 2 heard - a total of 95 species identified.

It is interesting to compare the two lists.

There were 62 species seen both in 1902 and 1955:

Common Loon, Holboell's Grebe, Horned Grebe, White Pelican, Double-crested Cormorant, Great Blue Heron, Black-crowned Night Heron, Bittern, Canada Goose, Mallard, Pintail, Shoveller, Green-winged Teal, Blue-winged Teal, Redhead, Canvasback, Lesser Scaup, Bufflehead, Ruddy Duck, Red-tailed Hawk, Marsh Hawk, Sparrow Hawk, Ruffed Grouse, Sharp-tailed Grouse, Sora Rail, Coot, Killdeer, Wilson's Snipe. Marbled Godwit, Wilson's Phalarope, Forster's Tern, Black Tern, Shorteared Owl, Nighthawk, Belted King- 
fisher, Yellow-shafted Flicker, Eastern Kingbird, Eastern Phoebe, Horned Lark, Tree Swallow, Cliff Swallow, Purple Martin, Crow, House Wren, Long-billed Marsh Wren, Catbird, Brown Thrasher, Robin, Cedar Waxwing, Loggerhead Shrike, Red-eyed Vireo, English Sparrow, Western Meadowlark, Yellow-headed Blackbird, Red-winged Blackbird, Bronzed Grackle, Cowbird, Rosebreasted Grosbeak, Goldfinch, Chipping Sparrow, Clay-colored Sparrow, Song Sparrow.

Congdon in 1902 saw 16 species that we did not identify in 1955: Eared Grebe, Western Grebe, Turkey Vulture, Bald Eagle, Sandhill Crane, Virginia Rail, Least Sandpiper, Black-billed Cuckoo, Horned Owl, Ruby-throated Hummingbird, Yellow-bellied Sapsucker, Hairy Woodpecker, Bobolink, Slate-colored Junco, White - throated Sparrow, Snow Bunting (on May 13th).

In 1955 we identified 33 species that Congdon did not: Gadwall, Baldpate, Ring-necked Duck, American Goldeneye, White-winged Scoter, Swainson's Hawk, Hungarian Partridge, Ring-necked Pheasant, Willet, Lesser Yellowlegs, Spotted Sandpiper, Solitary Sandpiper, Avocet, Ring-billed Gull, Franklin's Gull, Common Tern, Mourning Dove, Downy Woodpecker, Alder Flycatcher, Least Flycatcher, Bank Swallow, Barn Swallow, Magpie, Black-capped Chickadee, Veery, Mountain Bluebird, European Starling, Warbling Vireo, Yellow Warbler, Brewer's Blackbird, Baltimore Oriole, Savannah Sparrow, Vesper Sparrow.

The chief changes which have taken place in the bird life since 1902, seem to be the decrease in numbers or disappearance of a few larger - the Sandhill Crane, Turkey Vulture, and Bald Eagle (the latter was found nesting by Congdon at Middle Lake on May 29, 1902). In the intervening years, the Hungarian Partridge, Ring-necked Pheasant and European Starling arrived, having been introduced from other lands. The Barn Swallow and Magpie probably followed the opening of settlement to some extent.

Only a few years ago, there was a note by a Dr. R. T. Congdon of
Wenatchee, Wash., reporting on the finding of the nest of a Hudsonian Godwit at Churchill. I wrote to Dr. Congdon to inquire whether he might be related to the Russell $\mathrm{T}$. Congdon who wrote "Saskatchewan Birds" fifty years previously. Imagine to my surprise, he wrote to say that he was the same Russell T. Congdon. Coincidence goes further. He had, a year or two after his visit to Saskatchewan, entered Medical College. $\mathrm{He}$ was interested in the letterhead on which I had written - a family group in medical practice (Drs. Houston, Houston \& Houston). He replied on the letterhead of his family medical group - (Drs. Congdon, Congdon \& Congdon) - (a father and two sons).

At Kinistino, we met J. G. Young at the edge of Waterhen Marsh. When Mr. Young was twelve years of age, R. T. Congdon had boarded at his parent's farm while studying the birds of Waterhen Marsh.

Dr. Congdon has continued to enjoy his hobby of studying and photographing birds. Earlier this year he published his book "Our Beautiful Western Birds" (Exposition Press, 1954 , price $\$ 9.00$ ) illustrated with 185 of his magnificent photographs. Of special interest is the fact that one chapter - pages 293 to 305 - is entitled "A College Boy Explores Saskatchewan" and tells of his trip of 1902 .

\section{The Liver Bird}

By E. W. VAN BLARICOM, Tisdale

This summer, while in Europe, Mrs. Van Blaricom and I saw a most unusual bird.

As a matter of fact we saw four most unusual birds on top of a great building in Liverpool, England. We had great difficulty in identifying them. Personally I thought they were Albatrosses. It turned out that they were the Liver bird, a native of Liverpool. As a matter of fact Liverpool gets its name from the fact that it is the home of the Liver bird. The Liver bird does not exist at the present time. It lived in England at the same time as the Unicorn. 